J. Clin. Chem. Clin. Biochem.

Vol. 16, 1978, pp. 11-13

\title{
Chelation of Ambilhar with Calcium and Magnesium
}

\author{
By T. M. N. Al-Khayat, F. T. Abdul Aziz, N. N. Izzat
}

Department of Biochemistry and Physiology, Faculty of Medicine, Mosul University, Mosul, Iraq,

and

M. Salah, Kuwait

Received February 28/June 1, 1977)

Summary: The effects of Ambilhar (niridazole or nitrothiazole) on the calcium, magnesium and phosphorus contents of various tissues of rabbits were studied. It results in a decrease in the calcium content of bones, liver and muscles. A similar depletion of the magnesium content of brain, blood, liver and muscles was observed. On the other hand, the urinary excretion of calcium and magnesium was increased. These facts indicate that the drug possibly chelates with these divalent cations. This is supported by the ultra violet spectra of the complexes prepared in vitro.

The effect of Ambilhar on tissue phosphorus seems to be indirect. The phosphorus contents of both blood and urine are decreased. This could be due to an increased calcium concentration.

These findings may explain the toxic effects of Ambilhar on the nervous system.

\section{Chelatbildung von Ambilhar mit Calcium und Magnesium}

Zusammenfassung: Die Wirkung von Ambilhar (Niridazol; Nitrothiazol) auf dem Calcium-, Magnesium- und Phosphatgehalt verschiedener Gewebe von Kaninchen wurde untersucht. Ambilhar hat eine direkte vermindernde Wirkung auf den Calciumgehalt von Knochen, Leber und Muskel. Die gleiche Wirkung wurde am Magnesiumgehalt von Gehirn, Blut, Leber und Muskel beobachtet. Die Ausscheidung von Calcium und Magnesium im Harn war erhöht. Diese Befunde weisen auf eine mögliche Wirkung von Ambilhar als Chelatbildner für diese zweiwertigen Kationen hin. Diese Auffassung wird durch die UV-Spektren von in vitro dargestellten Komplexen gestützt.

Die Wirkung von Ambilhar auf den Gehalt der Gewebe an Phosphat scheint indirekter Natur zu sein. Der Phosphatgehalt sowohl des Blutes als auch ịm Harn fiel ab. Dies könnte an der erhöhten Calciumkonzentration liegen.

Die Ergebnisse könnten die toxischen Wirkungen von Ambilhar auf das Nervensystem erklären.

\section{Introduction}

Earlier studies on Ambilhar (niridazole or nitrothiazole) demonstrated its direct effect on body iron. Salah et al proved that the drug decreased serum as well as liver iron. At the same time the drug increased urinary iron output. Later, $A b d e l$ Aziz et al (2) showed that the drug chelated body iron. The side effects of Ambilhar on the central nervous system (3) lead us to investigate its effects on some other body minerals. The earlier studies of Fitzgerald (4) and Flink (5) showèd that magnesium deficiency resulted in muscle tremor, twitching, convulsions and delirium. These symptoms were also observed in our hospital patients treated with Ambillhar for billharziasis.
The aim of this study is to investigate the effects of Ambilhar on body calcium, magnesium and phosphorus.

\section{Material and Methods}

In vivo investigations

Twenty normal rabbits of the domestic type found in the Middle East, with an average body weight of $1.5-2 \mathrm{~kg}$, were used for our study. They were fed with ordinary fresh vegetables collected for animals in the college animal house. They were classified into two equal groups. Group $A$ were used as the control and group B were treated with Ambilhar as an aqueous suspension administered by stomach tube. A daily dose of $200 \mathrm{mg}$ for five consecutive days was given to each animal. The urine of each separate rabbit was collected daily in a metabolic cage. Urine samples were ashed and analysed quantitatively for their calcium, magnesium and phosphorus contents. At the end 
of treatment all animals were killed by bleeding. Samples of fresh blood from each animal were ashed and analysed for the above-mentioned minerals. A known weight of bone, muscle, brain and liver was obtained from each rabbit. These samples were dried at $105^{\circ} \mathrm{C}$ and then ashed in a muffle furnace at $500^{\circ} \mathrm{C}$ for 4 hours. The ash was used for the determination of these minerals by colorimetric methods after dissolving in $90 \mathrm{~g} / \mathrm{kg} \mathrm{HCl}$.

Calcium was measured by the chloranilic acid method described by Ferro \& Ham (6) and Chiamori (7). Magnesium was determined using the method of Neill \& Neely (8). The phosphorus content of the ash was measured by the Fiske \& Subbarow method (9).

\section{In vitro investigations}

Samples of Ambilhar (200 mg each) were mixed with $50 \mathrm{mg}$ calcium carbonate, or $50 \mathrm{mg}$ magnesium carbonate respectively. The whole mixture was rendered alkaline by adding sodium carbonate solution $(100 \mathrm{~g} / \mathrm{l})$ till $\mathrm{pH} 10-11$. The final volume was adjusted by adding distilled water to $25 \mathrm{ml}$. The whole mixture was boiled on a water bath where a clear brown solution was obtained. The complexes formed ran as single spots on a thin layer chromatogram. The complexes formed contain organically bound calcium and magnesium respectively. The ultra violet spectra of these two complexes against Ambilhar were recorded.

\section{Results}

Table 1 shows the effect of Ambilhar on the calcium, magnesium and phosphorus contents of various tissues in normal rabbits. The calcium concentration decreases in bones, liver and muscles with a concomitant increase in the contents of blood and urine. Similar results were obtained for the magnesium concentration of blood, liver and muscles, but the bone magnesium concentration was not significantly altered. On the other hand, the phosphorus concentration in blood and urine was significantly decreased.

The ultra violet spectra (fig. 1) of Ambilhar complexes with calcium and magnesium show that the thiazole ring (absorption spectrum at $370 \mathrm{~nm}$ ) was shifted to $410 \mathrm{~nm}$.

\section{Discussion}

Table 1 demonstrates the effects of Ambilhar on body calcium, magnesium and phosphorus in normal rabbits. Bone calcium was decreased by administration of the

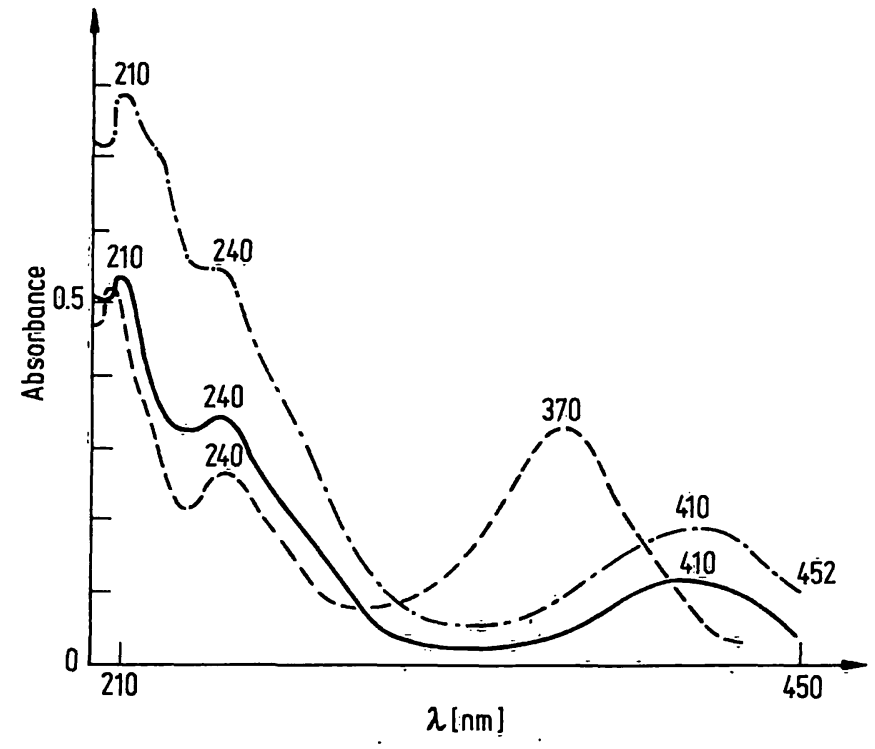

Fig. 1. Ultra violet spectra of Ambilhar (-- - ) and of the complexes of Ambilhar with calcium ( - ) and magnesium (-*-). This shows that the thiazole ring is mainly responsible for the suggested chelation.

drug, with a concomitant increase in its blood level and urinary output. It could be due to the accumulation of the Ambilhar-calcium complex in blood and its excretion in the urine. During metabolism the drug may mobilise calcium from the bones to the blood. Furthermore liver and muscle calcium levels were significantly decreased. This might be explained by the rapid detoxication of the drug in the liver by chelation with liver calcium.

On the other hand blood magnesium showed a significant decrease, while bone magnesium was not affected. Urinary excretion of magnesium showed a significant increase, while brain and muscle magnesium contents showed a marked decrease after administration of the drug. These findings could explain the serious side effects of the drug on the nervous system, which were found in patients (3). Again this could be explained by the chelating power of the drug with blood, liver and muscle magnesium. These facts are supported by the previous statement that Ambilhar is a strong iron chelating agent (2). It is therefore suggested that Ambilhar

Tab. 1. Effects of Ambilhar on the calcium, magnesium and phosphorus contents of various tissues in normal rabbits (mmol/ $/ \mathrm{kg}$ dry weight and $\mathrm{mmol} / \mathrm{l}$ ).

\begin{tabular}{lcccccc}
\hline Tissue & control & $\begin{array}{c}\text { Calcium } \\
\text { dosed }\end{array}$ & control $\ldots$ & $\begin{array}{c}\text { Magnesium } \\
\text { dosed }\end{array}$ & control & $\begin{array}{c}\text { Phosphorus } \\
\text { dosed }\end{array}$ \\
\hline Bone & $7.16 \pm(0.39)$ & $5.81 @ \pm(0.35)$ & $0.23 \pm(0.02)$ & $0.23 \pm(0.02)$ & $4.66 \pm(0.39)$ & $4.69 \pm(0.43)$ \\
Brain & $0.52 \pm(0.13)$ & $0.61 \pm(0.15)$ & $4.09 \pm(0.04)$ & $2.63 @ \pm(0.23)$ & $12.2 \pm(1.68)$ & $15.57 \pm(1.65)$ \\
Blood & $2.8 \pm(0.14)$ & $4.58 @ \pm(0.31)$ & $1.01 \pm(0.05)$ & $0.48 @ \pm(0.05)$ & $0.81 \pm(0.02)$ & $0.50 @ \pm(0.04)$ \\
Liver & $1.25 \pm(0.13)$ & $0.01 @ @ \pm(0.01)$ & $0.09 \pm(0.02)$ & $0.05 @ @(0.01)$ & $4.69 \pm(0.58)$ & $5.66 \pm(0.58)$ \\
Muscles & $2.12 \pm(0.3)$ & $0.47 @ @ \pm(0.06)$ & $0.13 \pm(0.02)$ & $0.05 @ \pm(0.03)$ & $5.18 \pm(0.72)$ & $5.86 \pm(0.73)$ \\
Urine & $120.75 \pm(1.70)$ & $131 @ \pm(2.4)$ & $0.15 \pm(0.05)$ & $0.42 @ \pm(0.8)$ & $0.61 \pm(0.06)$ & $0.32 @ \pm(0.19)$ \\
\hline
\end{tabular}

\pm standard deviation. @ significant at $5 \%$ level of probability. 
shows similar chelation behaviour with some divalent cations in vivo, thus resulting in their depletion.

It is most probable that the decrease of phosphorus concentration in blood and urine is secondary to the increase of the calcium level in these two fluids.

\section{References}

1. Salah, M. K., Hammady, 1. M., Hamed, M. Y. \& Abdel Aziz, F. T. (1970), Zentralbl. Veterinaermed. Reihe A. 17, 257-260.

2. Abdel Aziz, F. T., Al-Mallah, A. K. \& Hassanein, R. R. (1976), Zentralbl. Veterinaermed. Reihe A. 23, 475-478.

3. Martindale, W. (1973), The Extra Pharmacopoeia 26th. Ed. London, The Pharmaceutical Press. 17 Bloomsburry Sq. W. C. 1. p. 1618-1619.

4. Fitzgerald, M. G. \& Fourman, P. (1956), Clin. Sc. 15, 635-647.
Finally the preperation of a complex containing Ambilhar with both calcium and magnesium in vitro may support the previous in vivo finding. The ultraviolet spectra of the formed complexes show that chelation with calcium and magnesium occurs through the thiazole ring of Ambilhar (fig. 1).
5. Flink, E. B., Mc.Collister, R., Prasad, A. S., Melby, J. C. \& Doe, R. P. (1957), Ann. Int. Med. 47, 956-958.

6. Ferro, P. V. \& Ham, A. B. (1957), Am. J. Clin. Pathol. 28, 208-217.

7. Chiamori, N. \& Henry, R. J. (1958), Proc. Soc. Exp. Biol. Med. 97, 817-819.

8. Neill, D. W. \& Neely, R. A. (1956), J. Clin. Pathol. 9, 162-163.

9. Fiske, C. H. \& Subbarow, Y. (1925), J. Biol. Chem. 66, $375-400$.
Dr. F. T. Abdel Aziz, Biochem. Dept. Fac. of Med. Mosul Univ.

Mosul, Iraq 
。 